\title{
Служит ли форма выживанию? Опыт наследования памяти о Холокосте и психологические функции его нарративизации в прозе Магдалены Тулли
}

\begin{abstract}
AвSTRACT: Adelgejm Irina, Sluzhit li forma vyzhivaniiu? Opyt nasledovaniia pamiati o Holokoste i psihologicheskiie funkcii ego narrativizacii v proze Magdaleny Tullli (Does the Form Serve Surviving? The Experience of Inheriting the Memory of the Holocaust and Psychological Functions of It's Narrativization in Prose of Magdalena Tulli). "Poznańskie Studia Slawistyczne" 16. Poznań 2019. Publishing House of the Poznań Society for the Advancement of the Arts and Sciences, Adam Mickiewicz University, pp. 15-32. ISSN 2084-3011.

The article considers the experience of inheriting the traumatic memory in prose of Magdalena Tulli and autopsychotherapeutic functions of it's narrativization with the help of elements of psychotherapeutic methods (family constellations, a dialogue with a child in yourself, deconstruction and reconstruction of the life narratives, re-membering, therapeutic metaphor, focusing). The narrativization of the trauma in the process of artistic narration contributes processing traumatic experience, is an important element of constructing of autobiography, gives a chance to retrieve own history, which is not overshadowed with tragic parental discourse, helps to achieve balance between traumatic and positive contents of autobiographical memory, fulfills interpsychological functions.
\end{abstract}

KEYwORDS: Holocaust; postmemory; autobiographical memory; verbalization for traumatic experience; constructing of autobiography

Дебютный роман Магдалены Тулли (р. 1955) Сны и камни (1995), а также последовавшие за ним Красное (1998), Шестеренки (2003) и Изъян (2006) - тексты, построенные на развернутых метафорах - стали одним из ярчайших элементов процесса обновления художественного языка в польской прозе после 1989 г., которое осуществило, прежде всего, младшее литературное поколение 1990-х гг. 
Две последние книги Тулли, на первый взгляд, столь отличающиеся от ранней прозы - сборник рассказов Итальянские шпильки (2011) и роман Шум (2014) - были прочитаны в совершенно ином контексте: художественного воплощения наследования травмы Холокоста детьми Выживших, чье детство оказалось омрачено не пережитым ими прошлым, а унаследованная травматическая память стала личным болезненным опытом, в котором сложно взаимодействуют измерения личного и коллективного (проза Э. Курылюк, А. Тушиньской, Б. Кефф, М. Шнайдерман).

Феномен, описываемый Тулли в Итальянских шпильках и Шуме, - наследование замалчиваемой, вытесненной травмы (в интервью писательница говорит, что «всегда знала» [Wywiad, 2011] о том, что мать и тетка пережили лагеря, однако об этом не говорили; фраза «Мать скрывала тайну» в романе - одна из ключевых [Tulli, 2014, 9, 23, 31, 34]) - был весьма характерен для послевоенной Польши. Немота свидетелей Холокоста, связанная с неспособностью человека вместить опыт смерти в сознание и повседневную жизнь, имела в данном случае также конкретные макропсихологические, социологические, политические причины. В условиях антисемитизма уцелевшие на территории Польши или вернувшиеся сюда польские евреи продолжали скрывать свое происхождение. В результате память о Холокосте оказывалась травмирующей двояко - не только сама по себе, но и как опыт, который не только не может быть символически «обменян» на чувство гордости за предков и признание в обществе, но, напротив, представляет собой весьма рискованный капитал. Так, парадоксальным образом, массовая травма начинала переживаться как индивидуальная, не усиливающая, а разрушающая солидарность, поскольку являлась «источником повествования, которое нельзя разделить с другими» (Cyrulnik, 2014, 164). Невозможность говорить о своем опыте «замораживала» болезненные воспоминания, дополнительно травмируя выживших. Второе же поколение росло или со смутным ощущением непонятной инакости, или в чисто католической традиции. Возникали, по словам психиатра К. Швайцы, «заговор молчания», «двойная стена тишины» (Szwajca, 2011, 13) родители не говорили, а дети не спрашивали. Парадоксальное сочетание передающейся тем не менее невербально памяти (Fresco, 1984, 
421) и барьера безмолвия деформировали коммуникацию, вызывали у детей Выживших чувство вины. Лишь после 1989 г. было создано общество «Второе поколение - потомки уцелевших во время Холокоста». Однако неслучайно автобиографическая проза Тулли, Кефф, Курылюк, Тушиньской, Шнайдерман появляется лишь в 2000-е гг. эта генерация не сразу оказалась способна открыто говорить о своей истории и истории своей семьи.

Характерно, что на самом деле Тулли касалась проблемы Холокоста и памяти о нем во всех произведениях, предшествовавших «Итальянским шпилькам» и «Шуму», - однако лишь путем метонимии (Cuber, 2013), метафор, аллюзий, повторяющихся мотивов ${ }^{1}$ (Чужие, в которых внезапно обращаются бывшие соседи; психология в этом контексте «своих» [Tulli, 2006a, 78, 81, 102; 2006b, 62, 65, 66, 130]; топос пустоты, отсылающий к «бесследному исчезновению» еврейского населения Польши [Tulli, 2006b, 165-166], аллюзии с довоенными еврейскими фабрикантами, погромами [Tulli, 1998, 148], с Лодзью, городом, в котором находилось одно из крупнейших в Польше еврейских гетто и который стал после войны одним из мест наибольшего скопления Выживших; с варшавским гетто, курсировавшим через него трамваем, Умшлагплац [Tulli, 2006b, 62, 65, 66, 130, 78, 81, 72, 77], повязками на рукаве и желтым цветом [Tulli, 2006b, 69], «окончательным решением еврейского вопроса» [Tulli, 2006b, 139] и пр.). Однако до появления открыто автобиографических книг эти аллюзии неверно или не вполне верно интерпретировались. Так, поэтику первых романов Тулли большинство критиков и литературоведов связывало исключительно с постмодернистским понятием мира-текста, немногие видели в них параболу истории XX в., и никто еще не мог разглядеть в этих произведениях отзвуки личной травмы (лишь после выхода Итальянских шпилек автор рецензии замечает: «То, что в тех романах являлось моделью “истории”, здесь предстает закамуфлированной автобиографией автора» [Sobolewski, 2012]). Более того, в случае романа «Изъян» это привело и к принципиально неверному

${ }^{1}$ Так же, как и Э. Курылюк в романах Century 21 (1992), Grand Hotel Oriental (1997), Эротоэнциклопедия (2001), предшествовавших автобиографическим Гольди. Апология звероватости (2004) и Фраскати. Апология топографии (2009). 
истолкованию этической интенции, двигавшей автором. Повествователь здесь безжалостно примеривает к себе роли, отсылающие, прежде всего, к перспективе поляка - пассивного (или лишь на мгновение «тронутого собственной добротой» [,„poruszony własną dobrocią”; Tulli, 2006b, 70]) свидетеля Холокоста: «Дело зашло уже так далеко, что для меня нет другого выхода, кроме как признаться: я - часть этой толпы. Кроме как взять на себя неприятное бремя принадлежности к ней. Раз невозможно от нее бежать» („Sprawy zaszły już tak daleko, że nie ma dla mnie innego wyjścia niż przyznać się do tego tłumu. Niż wziąć na siebie kłopotliwy ciężar przynależności. Skoro nie da się od niej uciec" [Tulli, 2006b, 161]). Этот прием был прочитан (Przymuszała, 2008)² как попытка самообвинения польского автора: «Польская память имеет и будет иметь изъян. Но этот изъян - не приговор. Осознание его [...] - первый шаг в сторону выхода из разрушительного круга его воздействия» (Przymuszała, 2008, 152).

Полностью посвященные проблеме наследования травматической памяти, жизни в тени замалчиваемого трагического опыта Итальянские шпильки и Шум психологически и эстетически составляют, в сущности, единое повествование. Пережившие лагеря мать и тетка героини отгораживаются от мира (Tulli, 2014, 7, 8, 34; 2011, 81), являя собой пример своеобразного «аутизма» травмированного человека, который, по словам французского нейропсихолога Б. Цирюльника, становится «узником собственной гиперпамяти» (Cyrulnik, 2014, 48). Мать, изо всех сил имитирующая «нормальность» (,normalność”; Tulli, 2011, 25-26; 2014, 8, 93-95), словно бы «заморожена» эмоционально, опустошена (Tulli, 2011, 30, 28-29, 32, 35, 81, 94; 2014, 119, $80,82,97)$, слова «мертвый», «мертвенность» („martwy”, „martwota”) применительно к дому оказываются здесь одними из ключевых (Tulli, $2014,83,84,118)$. Сознание перенесенных страданий не позволяет ей

\footnotetext{
${ }^{2}$ Следует, впрочем, заметить, что автор придерживается той же точки зрения и в монографии, вышедшей уже после появления Итальянских шпилек и Шума Тулли: «роман становится признанием вины, указанием на соучастие в преступлении» (Przymuszała, 2016, 146). Однако ценным представляется замечание исследовательницы о том, что эзопов язык романа может интерпретироваться «как попытка защитить того, кто признается, и одновременно как знак, свидетельствующий о [...] состоянии польской памяти об уничтожении евреев» (Przymuszała, 2016, 149).
} 
принять заведомо несопоставимые с собственным прошлым проблемы дочери (Tulli, 2014, 12-13, 34, 84, 119; 2011, 32, 81, 88, 94). Разъединенность выражается также в употреблении терминов родства: мать нигде не названа «мамой» - только «моей матерью», «матерью» („matka”, „moja matka”); в рассказе «Кофейная гуща» повествовательница говорит о том, что «этому слову $[. .$.$] ребенок [. .$.$] не научился.$ Ни на одном языке» (,Tego słowa [...] dziecko [...] się nie nauczyło. W żadnym języku" [Tulli, 2011, 31]).

Матрицентрическое повествование словно бы символизирует неизбежность наследования травмы, ее симбиотический (Рупперт, 2015) характер. Эти тексты описывают последствия жизни рядом с травмированной матерью. Ее молчание словно бы эхом отзывается в проблемах маленькой героини с чтением и письмом (Tulli, 2011, 80-104; 2014, 8, 17), заставляет замолчать и буквально (Tulli, 2011, $31,81)$; деформация связи мать/дочь приводит к неприятию ребенком самого себя (Tulli, 2011, 102), неумению строить отношения в дальнейшем (Tulli, 2014, 80, 87, 82). Материнское прошлое делает реальным, физически ощутимым присутствие в повседневной жизни дочери эсэсовцев (Tulli, 2014, 43-44, 73), бывшая жертва передает ей готовность, в свою очередь, стать жертвой (Tulli, 2011, 75, 142-143). Наследуется ощущение непрочности бытия (Tulli, 2011, 30-31, 121, 142, 73-74; 2014, 8, 86), навязчивый страх (Tulli, 2011, 142), возникает ощущение собственной гибели в непережитом прошлом: «Я бы хотела забыть, что погибла в Освенциме» („Chciałabym zapomnieć, że zginęłam w Auschwitz" [Tulli, 2011, 75]); «все мы погибли [...] Да, мы погибли. Вот почему я живу в полсилы» (,wszyscy zginęliśmy [...] Tak, zginęliśmy. Oto dlaczego żyję tylko na pół gwizdka" [Tulli, 2011, 73]); «Меня не привезли в лагерь! Она [мать - И.А.] сама меня туда затолкала, мимоходом, словно бы походя» („Nie przywieźli mnie do obozu! Sama mnie tam wtrąciła, mimochodem, jakby przez nieuwagę" [Tulli, 2011, 36]); «Меня застрелили столько раз, что и не сосчитать» (,Zostałam zastrzelona tyle razy, że nie da się zliczyć” [Tulli, 2011, 121]).

Унаследованная от матери травма Холокоста усугубляется атмосферой царящего в послевоенной Польше едва прикрытого насилия: «война, однажды начавшись, не имеет конца» - «подобно имуществу банкрота, она переходит в собственность следующих поколений» 
(„wojna, jeśli już się zacznie, nie ma końca” - ,jak masa upadłościowa, przechodzi na własność potomnych" [Tulli, 2011, 64]). Неслучайно это слово оказывается своеобразным лейтмотивом обоих произведений - Тулли демонстрирует универсальный механизм воспроизведения насилия на разных уровнях жизни общества (Tulli, 2011, 37, 65, 77, $120132,134 ; 2014,31,32,35,49,51,55,57,59,60,66-68,74,97,132)$. В атмосфере антисемитизма, когда дети и взрослые охотно пользуются в качестве угрозы аллюзиями на реалии оккупации [Tulli, 2011, 9, $14,20,16,20,139]$, героиню мучит ощущение неуловимой инакости, жизнь отравляет бремя не высказанных взрослыми страхов и висящей в воздухе угрозы со стороны окружающих, т.е., так или иначе, смутное ощущение опасности, исходящей из замалчиваемого прошлого - «Откуда ей было знать, что проблемы, с которыми она не могла совладать, старше нее. Что они [...] порождены предыдущим миром» (,Skąd miała wiedzieć, że kłopoty, z którymi nie potrafi się uporać, są starsze od niej. Że [...] wzięły się z poprzedniego świata" [Tulli, 2011, 120]).

Художественное воплощение автобиографической памяти - «аутопоэтического» (Рождественская, 2012, 44) процесса постоянной реинтерпретации и реструктуризации воспоминаний с учетом текущих потребностей - обладает ярко выраженными психотерапевтическими функциями (Адельгейм, 2018). Особое значение имеет вербализация травматического опыта, который не поддается автоматическому встраиванию в привычные схемы понимания. Нарративизация травмы помогает перейти от некритического проигрывания к рефлексивной проработке (LaCapra, 2009, 502; 2015, 528), повествование выстраивает травматическое событие в цепочку событий, придавая ему характер биографического опыта.

У Тулли, как и в других повествованиях второго поколения детей Холокоста, аутопсихотерапия симбиотической травмы, связанной с наследованием травматической памяти, осуществляется, в первую очередь, при помощи эмпатического повествования, в котором обнаруживаются параллели с методом семейных расстановок Хеллингера, основанном на предположении, что источник проблемы пациента может находиться в жизни предков. Чтобы освободиться от унаследованной травмы, необходимо простить мать, для прощения же мало 
просто понимания, рационального осмысления, предположений - необходимо эмпатическое воспроизведение в повествовании тех моментов в опыте матери, которые сделали ее такой, какой ее узнала дочь, т.е. своего рода виртуальное проживание их. Эмпатическая реконструкция судьбы предков направлена на освобождение как их памяти, так и собственного сознания от печати стыда («Единственное в них, что подлежит наследованию, в том числе и мною, - стыд» [,,Jedyne, co w nich podlega dziedziczeniu i w czym mam swój udział, to wstyd"; Tulli, 2011, 74]) и страха (характерно, что в финале романа повествовательница «добирается» до довоенного детства матери, стоит на пороге встречи с ней, еще не травмированной историей [Tulli, 2014, 133]), выражение того, что осталось невыраженным, невысказанным ими. Так, например, лишь после смерти матери героиня Тулли узнает, чтó же стало причиной ее состояния, отравившего детство дочери не только сама травма Холокоста, но и потрясение, шок, стресс после освобождения, вторичная травма, накладывающаяся на первую и связанная с отсутствием понимания, эмпатии, с необходимостью подавлять свои чувства (Tulli, 2014, 131-132). Эта последняя капля страдания, которая сделала травму Холокоста необратимой, подтверждает слова Л. Гилмор о том, что «ключевое значение для опыта травмы имеют трудности, которые возникают на пути ее выражения» (Gilmore, 2015, 366).

Эмпатическое повествование также восполняет утраченную в процессе исторического катаклизма связь между поколениями (что Л. Лангер называет одним из главных преступлений нацизма [Langer, $2004,127])$, выполняя, таким образом, коммуникационную функцию.

По Хеллингеру, к семейной системе относятся не только родственники, но и люди, связанные с человеком отношениями масштаба жизни и смерти. Наглядный образ такой «семьи» дает роман Шум: в зале фантасмагорического Низшего суда появляются, помимо главных героев и участников их жизни, с одной стороны, убитые эсэсовцы, с другой - их жертвы (Tulli, 2014, 127) («Всё это одна семья» [„,То wszystko rodzina"; Tulli, 2014, 128]).

Согласно методу семейных расстановок, главным источником психологических проблем у последующих поколений является исключение (т.е. забвение) кого-либо из участников травмы из семейной 
системы (будь то пострадавшие или виновные). Метод помогает обнаружить и включить в свою историю эти «выпавшие» фигуры. В романе «Шум» эта коррекция должна символически совершиться в Низшем суде: «- Мы все собрались сегодня [...] затем, чтобы... - начал лис и сделал паузу. - Чтобы осудить! - подсказал эсэсовец. - Чтобы простить, - закончил лис» (,Zebraliśmy się dzisiaj wszyscy [...] po to, żeby... zaczął lis i urwał. - Żeby się osądzić! - podpowiedział esesman. - Żeby sobie wybaczyć - dokończył lis") (Tulli, 2014, 116). Однако происходит она и иначе - посредством «нахождения», признания, эмпатического воспроизведения истории, включения в семью девочкой в своем воображаемом мире фигуры эсэсовца, который, с одной стороны, воплощает военное и послевоенное зло и насилие, с другой, является реальным человеком из замалчивавшейся матерью ее истории - не давшим узникам умереть и застреленным сразу после освобождения лагеря и не спасенным матерью (Tulli, 2014, 48, 127). Примечательно, что момент «нахождения» этого персонажа («Каждый раз, когда я смотрела на лиса и девочку, у меня возникало ощущение, что на моей картинке кого-то не хватает» [,Za każdym razem, kiedy przyglądałam się lisowi i dziewczynce, miałam wrażenie, że na moim obrazku kogoś jeszcze brakuje"; Tulli, 2014, 42]) почти буквально иллюстрирует принцип расстановок: «Если предмет запроса связан с переплетением, это проявляется в расстановке как [...] сильное ощущение “здесь кого-то не хватает”» (Веселаго, 2010, 2011). Следует добавить, что самим своим романом Тулли, по сути, заново вписывает в семейную систему и саму себя, исключенную в детстве.

Одним из важнейших лейтмотивов прозы Тулли оказывается мысль, с одной стороны, об общности наследия травматической памяти («наследственная масса является общей» [„Masa spadkowa jest wspólna”; Tulli, 2014, 55]), с другой - о невозможности обменять свою долю на чужую. Именно об этом - обмене размыто-мучительной наследственной памяти жертв на память виновных - мечтает повествовательница «Итальянских шпилек»: «Но если уж непременно лагеря - не лучше ли наследовать этим статистам, что прохаживались по плацу, постукивая прутиком по голенищу сапога? Самая тяжкая вина кажется легче такой шкатулки без ключика» („А jeśli już muszą to być obozy - czy nie lepiej dziedziczyć po tych statystach, którzy przechadzali 
się po placu, trzaskając trzcinką po cholewach butów? Najcięższa wina wydaje się lżejsza od takiej kasetki bez kluczyka" [Tulli, 2011, 75-76]). Повествователь романа Изъян бесконечно примеряет к себе именно эту, другую, память - т.е. роли пассивных и активных соучастников преступления, совершаемого против «чужих» (метонимии Холокоста): «Если я - одна из этих уважающих себя домохозяек» („Јeśli jestem jedną z tych szanujących się gospodyń"); «если я - один из этих зевак» (,jeśli jestem jednym z tych gapiów”) и пр. (Tulli, 2006b, 66, 70, $103,117-118,133-134,138,153,158-159,171-172)$. В конце концов, повествователь все же принимает на себя роль наследника памяти жертв (автобиографическую, как знает сегодняшний читатель Тулли): «Если я - тот ребенок [...] а разве я могу быть кем-либо еще? [...] Желаю я того или нет, бездомная толпа, одетая то так, то иначе, будет появляться во всех историях, каким я в состоянии дать жизнь» (,Јеśli więc jestem owym dzieckiem [...] a czy mogę być kimkolwiek innym? [...] Czy tego chcę, czy nie, bezdomny thum, raz tak, raz inaczej ubrany, przewija się przez wszystkie historie, jakie umiem wprawić w ruch" [Tulli, 2006b, 171-172]). Однако в процессе повествования успевает «включить» в свою историю этих пассивных bystanders и от имени их наследников, гипотетически, испытать боль того, кто добросовестно несет бремя памяти о совершенном рядом зле: «Разве не являюсь я в ней фигурой последней из последних, той, которая, в конце концов, должна взять на себя всю боль?» („Czyż nie jestem w niej postacią najostatniejszą z ostatnich, tą, która w końcu musi wziąć na siebie cały ból?" [Tulli, 2006b, 164]). Таким образом, надежды генерала на то, что уничтоженные Чужие «умрут и обо всем забудут» («Вместе с ними исчезнут их страдания. Ни одна обида не отравит будущее» [,Razem z nimi znikną ich cierpienia. Żaden resentyment nie zatruje przyszłości”; Tulli, 2006b, 159]) оказываются тщетны вдвойне - травматическая память наследуется обеими сторонами.

Тулли использует также метод диалога с собственным детством. В рассказе «Ключ», повествование в котором ведется то от третьего, то от первого лица (а также частично в рассказе «Забавные слоги»), взрослая героиня-повествовательница визуализирует встречу с собой-ребенком, почти буквально воспроизводя психотерапевтические упражнения «Встреча с внутренним ребенком», «Формирование 
внутреннего родителя» (Шевцова, 2008, 14-15, 21). Это дает возможность исследовать детские переживания, сохраняющие свое влияние во взрослой жизни, дистанцироваться от травмы детства при сохранении ощущения целостности биографии (Tulli, 2011, 122).

В прозе Тулли можно обнаружить также элементы нарративной психотерапии (метода, исходящего из концепции гипотетической полиисторичности любой жизни и возможности изменения в процессе интерпретации доминирующего нарратива). Этот процесс заключается в «перерассказывании», реинтерпретации собственной жизни с целью коррекции самоидентификации (в данном случае - самоощущения жертвы насилия и памяти о насилии) и включает в себя анализ доминирующего нарратива, нахождение и уплотнение прежде периферийных эпизодов с целью создания альтернативной истории, «восстановление участия» - вовлечение, проживание заново и переоценку истории взаимоотношений со значимыми другими (Уайт, 2010, 149). Повествовательница совершает этот процесс в том числе словно бы от лица матери, обращаясь к свидетелям той части ее жизни, память о которой ей недоступна, частично переоценивая и перерассказывая при этом собственное детство. Яркий пример восстановления участия - показания «свидетелей» в уже упоминавшемся Низшем Суде (Tulli, $2014,118,117,122,119,121)$. Именно им спустя десятилетия удается нащупать суть симбиотической травмы: «Теперь я бы сказала, что она скрывала под свитером какую-то страшную рану. Не знаю, откуда она могла у нее появиться, ведь жизнь у нас тогда была спокойная. Что я хочу этим сказать? То, что говорю. Что она эту рану от матери унаследовала» (,,Teraz powiedziałabym, że nosiła pod sweterkiem jakąś straszną ranę. Nie wiem, skąd ją miała mieć, przecież wtedy wszyscy prowadziliśmy spokojne życie. Co chcę przez to powiedzieć? No przecież właśnie to mówię. Że odziedziczyła ją po matce" [Tulli, 2014, 119]). Пo сути же процессом восстановления участия значимых других является и все повествование.

Для прозы Тулли, как уже говорилось, характерны развернутые метафоры, которые, как утверждает писательница, являются для нее «не приемом на языковом уровне, но частью самого действия, началом действия»: «Собственно, действие заключается у меня в последствиях метафор. Можно сказать, что я подхожу к метафоре смертельно 
серьезно, то есть понимаю ее буквально. Это не украшение, а двигатель повествования» (Wywiad, 1999, 128). Часть метафор имеет также аутопсихотерапевтические функции.

Важнейшая роль психотерапевтической метафоры - диссоциирующая и моделирующая. Метафора - прежде всего, посредством номинализации - способствует экстернализации проблемы: человек рассматривается не как ее вместилище, а как субъект, находящийся с ней во взаимоотношениях, которые поддаются анализу и корректировке. Таковы метафоры, воплощающие обременительность детского опыта в тени материнского страдания в прозе Тулли: образ нежеланного наследства (Tulli, 2014, 55, 19, 66), тяжкого груза (Tulli, 2014, 27; Tulli, 2011, 65-66, 75), тучи и дыма как memento, символ вечного, преследующего потомков страдания жертв Холокоста (Tulli, 2011, 65-66, 75, 69, 125), раны, нанесенной матери и унаследованной дочерью (Tulli, 2014, 119-120) и пр.

В романе Шум используются также «в развитии» метафоры, выражающие ощущение неустойчивости и неуверенности героини. Одна из них, связанная с катком и умением/неумением держаться на коньках, напоминает «живые метафоры», применяемые Д. Миллс и Р. Кроули в работе с детьми («Живая метафора является прекрасным дополнением к рассказу, потому что помогает закрепить содержащийся в нем лечебный посыл через реальные физические ощущения. Рассказ пробуждает скрытые бессознательные ресурсы, а живая метафора дает им возможность проявиться в практической деятельности» [Миллс, Кроули, 2000, 74]). Первые коньки становятся знаком доли свободы, а первая попытка прокатиться по льду оказывается путем к преодолению внушенного дома и в школе комплекса неполноценности, обретение устойчивости на катке совпадает с ощущением обретения ее в повседневной жизни (Tulli, 2014, 79-86). Вторая метафора навязывается героине в детстве - это шуточное стихотворение об утке-чудачке, которым дразнит девочку двоюродный брат (Tulli, $2014,80)$. Последний раз утка незримо появляется за дверью Низшего суда, однако внутрь не заходит (Tulli, 2014, 118). Таким образом, «не пустив» утку внутрь, повествовательница завершает этот внутренний сюжет - перестает чувствовать себя жертвой: «- Чтобы мы сумели простить, если никто перед нами не извинился, - сказала я, - кому-то в нас придется умереть. - Кому? [...] Я поколебалась, но ответила: 
- Жертве» (,Żebyśmy mogłi przebaczyć, kiedy nikt nie przeprasza odezwałam się - ktoś w nas musi umrzeć. - Kto? [...] Zawahałam się, ale mu odpowiedziałam. - Ofiara" [Tulli, 2014, 123-124]). Очевидно, что эти две метафоры оказываются также элементами вышеупомянутой реконструкции жизненного нарратива.

Метафора инициирует трансдеривационный поиск - установление подобия жизненной и метафорической ситуации, поиск в памяти и рефлексиях референтного опыта, объясняющего настоящую ситуацию (Гордон, 1995, 21). Для облегчения решения повторяющейся проблемы та должна быть подвергнута рекалибровке. С этой целью может быть введен эквивалентный клиенту персонаж, который каким-либо образом нарушает прежнюю модель, в результате чего человек, в конце концов, обретает способность к эффективному изменению ситуации. В Шуме история с воображаемым лесом, в котором живут альтер эго маленькой героини и волшебный лис, олицетворяющий свободу, независимость и тайну, с одной стороны, предстает спасительной, играющей компенсаторную роль детской фантазией (Миллс, Кроули, 2000, 23), которую автор «дарит» себе-в-детстве («У меня была когда-то книжка-раскраска, в которой фигурировал лис. Но я с лисом не дружила. [...] Лис олицетворяет нечто, что во мне присутствует, но доступ к чему я получаю только в свои лучшие мгновения» [Wywiad, 2014a]; «Что касается лиса - он не был придуман для романа. Это часть меня, для литературных целей украшенная рыжим хвостом и чертами, которыми мне бы хотелось обладать всегда, а я обладаю ими лишь время от времени. [...] В детстве эта часть существовала во мне только в зародыше, а потом стала активно развиваться» [Wywiad, 2014b] - рассказывает писательница). С другой, это двусторонняя (на автобиографическом уровне, как становится ясно из интервью, направленная из взрослой жизни в детство, а на сюжетном - прорастающая из детства во взрослую жизнь героини) развернутая терапевтическая метафора-история, которая помимо сходства структуры, содержит в себе некоторый позитивный опыт, возможность облегчения конфликтной ситуации, предлагает замещение негативного опыта позитивным на основе их внешнего сходства. Характерны ассоциирование себя со зверем, который вынужден убегать от человека и отсылка к антисемитским 
терминам (гитлеровское «Judenjagd» и польское, времен кампании 1968 г., «крашеные лисы», используемое в рассказе Бегство лис). Обладающий таким опытом лис помогает девочке выжить, берет на себя функции воспитателя, советчика, способствует адаптации к собственным страхам, повышению самооценки (Tulli, 2014, 3841). Во взрослой жизни, после развода, героиня вновь встречает лиса, который приводит ее в Низший суд, призванный способствовать гармонизации ее внутреннего мира. Кроме того, как уже говорилось, в лесу обитает эсэсовец, воплощающий насилие - и внешнее, и собственную подавленную внутреннюю агрессию (поэтому девочка и лис символически связывают ему руки, это буквальное, наглядное действие становится возможным, благодаря персонификации проблемы и использованию метафоры-сказки).

В повествовании Тулли о наследовании травматической памяти можно увидеть также яркое воспроизведение метода фокусирования Ю. Джендлина (Джендлин, 2000) - прояснения и вербализации телесных ощущений, являющихся «камертоном» ощущения проблемной ситуации, что приносит облегчение само по себе, а также открывает дополнительные возможности для анализа проблемы (посредством своеобразной экстернализации проблемы путем определения ее «болевой точки» в границах тела, а затем нахождения для нее резонирующего с телесным переживанием проясняющего проблему образа). Героиню рассказа «Бегство лис» с детства преследует смоляная туча, которая символизирует бремя неосознанной памяти о Холокосте, годами вытеснявшуюся травму (Tulli, 2011, 124-127, 129-130, 139-140). Она вызывает эмоции (Tulli, 2011, 126-127), а затем то, что Джендлин называет «чувствуемым ощущением» (Tulli, 2011, 127-128), которое рационализируется, связывается с пониманием: «Что-то большое отделилось от сердца, поднялось и застряло в горле, причиняя мне боль. Тогда я все поняла. В этой черной туче, которую ветер гнал над морями и океанами, плыли по небу мои родственники» („Coś dużego oddzieliło się od mojego serca, ruszyło do góry i boleśnie utknęło w krtani. Wtedy wszystko zrozumiałam. W tej czarnej chmurze, niesionej wiatrem ponad lądami i morzami, płynęła po niebie moja rodzina" [Tulli, 2011, 140]). По словам Джендлина, «чувствуемое ощущение возникает в вашем теле, подобно подташниванию, 
указывающему на то, что определенные проблемы, с которыми, как вам казалось, вы уже разобрались, в действительности так и не разрешены» (Джендлин, 2000, 51). Именно это осознает героиня («Она уверена, что ничего не боится. А на самом деле постоянно чего-то боится. Всегда одного и того же - и ничего больше» [„,Ona wierzy, że nie boi się niczego. A przecież zawsze się czegoś boi. Zawsze tego samego i niczego więcej"; Tulli, 2011, 142]), находя затем, наконец, название для своего ощущения: «В этом-то все и дело. Страх душит eе, круглый и твердый, как шарик, детский мячик, невозможно ни выплюнуть его, ни проглотить» („Otóż właśnie. To strach ją dławi, okrągły i twardy jak piłka, jak dziecięca piłeczka, nie da się go wypluć, nie da się przełknąć" [Tulli, 2011, 142]).

Нарративизация травмы в процессе художественного повествования способствует, таким образом, переработке посттравматического опыта. В ситуации постпамяти, являющейся опытом детей Выживших (которую Д. Хирш неслучайно именует «заместительной травмой» (Hirsch, 2015, 256)), она оказывается важнейшим элементом строительства автобиографии, дает возможность обрести собственную историю, не заслоненную трагическим родительским дискурсом («Постпамять характеризует опыт тех, кто рос в среде, подчиненной повествованию, истоки которого относятся к периоду до их рождения. Истории предыдущего поколения, порожденные травматическим опытом, который не поддается ни пониманию, ни переработке, подминают под себя их собственные запоздалые истории» [Hirsch, 2010, 254]), помогает достичь «баланса между травматическими и поддерживающими позитивными содержаниями автобиографической памяти» (Нуркова, 2000, 23). Кроме того, повествование о травме выполняет не только интрапсихологические, но и интерпсихологические функции: порождает своего рода эмпатические сообщества, заставляя вспомнить слова Дж. Хирш о «связи собственной травмы с травмой другого»: травма «может вести к встрече с другим через саму возможность [...] прислушаться к чьей-то боли» (Hirsch, 2015, 284).

Это может стать значимой мотивацией и само по себе явиться аутопсихотерапевтическим актом в случае пережитой в детстве отверженности, как у Тулли: 
Первой и самой главной причиной боли было ощущение непринадлежности. [...] Издать книгу меня уговорили прочитавшие ее знакомые. Я думала, что она окажется мостиком между мною и другими людьми, поможет найти пространство общего опыта и это даст мне чувство принадлежности. [...] Я хотела почувствовать, что у меня есть что-то общее с другими людьми и хотела, чтобы у других было что-то общее со мной. [...] После авторского вечера несколько человек из зала подошли ко мне и сказали, что пережили нечто подобное этой истории. О, подумала я, - вот кусочек общего опыта. Позвонила издательнице - мол, хорошо, договорились, печатаем (Tulli, 2017, 98, 49, 90, 95).

\section{Это подтверждает слова нейропсихолога Б. Цирюльника:}

Когда группа исповедует один и тот же дискурс, присутствие других людей гарантирует каждому члену группы чувство безопасности. Рассказывание одной и той же истории, вера в одни и те же представления порождают чувство огромной близости. Поэтому повести, которые мы разделяем с другими людьми, мифы и общие молитвы действуют целительно (Cyrulnik, 2014, 164).

Разумеется, рассмотренные художественные тексты не являются не могут и не должны являться - последовательными курсами той или иной психотерапии. Более того, это тексты литературные, и их конечная форма, имеющаяся в распоряжении читателя, безусловно в значительной степени представляет собой результат этого процесса:

Если бы я хотела лечиться писанием, это невозможно было бы читать. Боль должна раствориться, она растворяется долго. Эмоции оседают, начинается работа разума. На это нужно время. [...] Чтобы я могла теперь об этом рассказывать, прежде нужно было рассказать все это самой себе. Спросить себя, чем это для меня являлось. Удивиться, что кто-то чего-то не сделал, что я чего-то не сделала. Найти того, кто захочет это выслушать (Tulli, 2017, 49-50).

Однако этот художественный, а не терапевтический - в буквальном смысле - текст, являясь записью уже частично или полностью проработанной травмы, всегда в той или иной степени представляет собой также и очередной вариант автобиографии, закрепляющий психологические изменения (как и изданное в 2017 г. отдельной книгой интервью-река - Какая прекрасная иллюзия).

Параллели, а порой и почти буквальное сходство с рядом психотерапевтических методов или их элементов, обнаруживающееся при анализе связанных с травмой текстов, очевидно, свидетельствуют 
о подспудном - более или менее очевидном - стремлении формы художественного текста к выполнению именно аутопсихотерапевтических, защитных функций, связанных с индивидуальными и коллективными травмами, а также - о силе структурированного слова. В этом случае на полуриторический вопрос Тулли - «А что такое форма, откуда она приходит и каким органом чувств мы ее ощущаем? И зачем она нам нужна, ведь, наверное, она не служит выживанию?» (Tulli, 2017, 108) - следовало бы возразить: художественная форма в конечном счете служит именно выживанию. Или, говоря словами одного из героев Мариуша Сеневича: «Язык, на него вся надежда. В конце концов, жизнь есть ни что иное, как фабула, сложенная из слов. Кто умеет рассказать себе собственную жизнь, тот познал счастье. Кто не умеет - тот увидит вместо своей жизни серию случайных фрагментов» (Sieniewicz, 2014, 48).

\section{Literatura}

Cuber, M. (2013). Metonimie Zagłady w polskiej prozie lat 1987-2012. Katowice: Uniwersytet Śląski.

Cyrulnik, B. (2014). Ratuj się, życie wzywa. Przeł. E. Kaniowska. Kraków: Czarna owca.

Fresco, N. (1984). Remembering the Unknown. „International Review of Psycho-Analysis" nr 11, s.17-27.

Gilmore, L. (2015). Przypadki graniczne: trauma, autoprezentacja i prawne formy tożsamości. W: Antologia studiów nad trauma. Przeł. K. Bojarska, T. Bilczewski i in. Kraków: Universitas.

Hirsch, M. (2010). Żałoba i postpamięć. W: Teoria wiedzy o przeszłości na tle wspótczesnej humanistyki. Antologia. Przeł. K. Bojarska. Poznań: Wydawnictwo Poznańskie, s. 245-278.

Hirsch, J. (2015). Postmodernizm, drugie pokolenie i międzykulturowe kino posttraumatyczne. W: Antologia studiów nad trauma. Przeł. K. Bojarska, T. Bilczewski i in. Kraków: Universitas.

LaCapra, D. (2015). Trauma, nieobecność, utrata. W: Antologia studiów nad trauma. Przeł. K. Bojarska, T. Bilczewski i in. Kraków: Universitas.

LaCapra, D. (2009). Pisanie historii, pisanie traumy. W: Pamięć Shoah. Kulturowe reprezentacje i praktyki upamiętnienia. Red. T. Majewski, A. Zeidler-Janiszewska, M. Wójcik. Łódź: Wydawnictwo Officyna.

Langer, L. (2004). Scena pamięci. Rodzice i dzieci w tekstach i świadectwach Holokaustu. Przeł. J. Mikos. „Literatura na Świecie” nr 1-2. 
Przymuszała, B. (2008). Skaza? - Holocaust jako problem polskiej pamięci. Szukanie opowieści. W: Narracje o Polsce. Red. B. Korzeniewski. Poznań: Wydawnictwo Poznańskiego Towarzystwa Przyjaciół Nauk.

Przymuszała, B. (2016). Smugi Zagłady. Emocjonalne i konwencjonalne aspekty tekstów ofiar i ich dzieci. Poznań: Uniwersytet im. Adama Mickiewicza w Poznaniu.

Sieniewicz, M. (2014). Walizki hipochondryka. Kraków: Znak.

Sobolewski, T. (2012). Magdalena Tulli: nie ma zmyślonych opowieści. „Gazeta Wyborcza", 15 września. http://wyborcza.pl/1,75475,12487543,Nike_2012_Magdalena_Tulli_Nie_ma_zmyslonych_opowiesci.html. 24.04.2018.

Szwajca, K. (2011). Rodziny po Zagładzie. „Midrasz” nr 6, s.10-19.

Tulli, M. (1998). W czerwieni. Warszawa: W.A.B.

Tulli, M. (2006a). Tryby. Warszawa: W.A.B.

Tulli, M. (2006b). Skaza. Warszawa: W.A.B.

Tulli, M. (2011). Włoskie szpilki. Warszawa: Nisza.

Tulli, M. (2014). Szum. Kraków: Znak literanova.

Tulli, M. (2017). Jaka piękna iluzja. Kraków: Znak literanova.

Wywiad (1999). Calvino, Marquez i pewna pani. Rozmowa z Magdalena Tulli. W: Czapliński, P., Śliwiński. P. Kontrapunkt. Rozmowy o książkach. Poznań: Obserwator.

Wywiad (2011). Ludzik mi padł, więc gram następnym. „Gazeta Wyborcza”, 30 października. http://wyborcza.pl/duzyformat/1,127291,10548289,Magdalena_Tulli Ludzik_mi_padl_wiec_gram_nastepnym.html?pelna=tak. 24.04.2018.

Wywiad (2014a). Prywatne klocki-wywiad z Magdalena Tulli. „Centrala”, 31 listopada. http://czytamcentralnie.blogspot.ru/2014/10/prywatne-klocki-wywiad-z-magdalena-tulli.html. 24.04.2018.

Wywiad (2014b). Zbuntowana - rozmowa z Magdalena Tulli. „Gazeta Wyborcza”, 26 września. http://wyborcza.pl/1,75410,16711994,Zbuntowana_rozmowa_z_ Magdalena_Tulli.html. 24.04.2018.

Адельгейм, И.Е. (2018). Психология поэтики. Аутопсихотерапевтические функцуии художественного текста (на материале польской прозы 1990-2010-х г2.). Москва: Индрик.

Веселаго, Е.В. (2010, 2011). Системные расстановки по Берту Хеллингеру: история, философия, технология. „Психотерапия” $\mathrm{nr}$ 7, $\mathrm{nr}$ 1. http://www. constellations.ru/paper.html. 24.04.2018.

Гордон, Д. (1995). Терапевтические метафоры. Оказание помощуи другим посредством зеркала. Санкт-Петербург: Белый кролик.

Джендлин, Ю. (2000). Фокусирование. Новый психотерапевтический метод работы с переживаниями. Пер. А.С. Ригина. Москва: Независимая фирма «Класс».

Миллс, Д., Кроули, Р. (2000). Терапевтические метафоры для детей и внутреннего ребенка. Пер. Т.К. Кругловой. Москва: Независимая фирма «Класс».

Нуркова, В. (2000). Свершенное продолжается: психология автобиографической памяти личности. Москва: УРАО. 
Рождественская, Е.Ю. (2012). Биографический метод в соииологии. Москва: Издательский дом Высшей школы Экономики.

Рупперт, Ф. (2015). Симбиоз и автономность. Расстановка при травме. Симбиотическая травма и любовь по ту сторону семейных переплетений. Пер. А. Соколовой. Москва: Институт консультирования и системных решений.

Уайт, М. (2010). Карты нарративной практики. Введение в нарративную терапию. пер. Д.А. Кутузова. Москва: Генезис.

Шевцова, И.В. (2008). Тренинг работы с собственным детством. Санкт-Петербург: Речь. 